Check for updates

Cite this: RSC Adv., 2017, 7, 49745

Received 3rd September 2017

Accepted 10th October 2017

DOI: 10.1039/c7ra09795f

rsc.li/rsc-advances

\section{Influence of bicarbonate on the abundance of microbial communities capable of reducing $U(v)$ in groundwater}

\begin{abstract}
Dianxin Li, Nan Hu, Yang Sui, Dexin Ding, (D) * Ke Li, Guangyue Li and Yongdong Wang
In order to investigate the influence of different concentrations of bicarbonate on the abundance of microbial communities capable of reducing $\mathrm{U}(\mathrm{VI})$ in groundwater, 7 groups of experiments incubated with lactate and amended with 7 initial concentrations of bicarbonate $(0,5,10,15,20,25$, and $30 \mathrm{mM})$, respectively, were conducted. It was found that $U(\mathrm{VI})$ concentration failed to decrease below the Chinese uranium wastewater discharge standard $\left(0.05 \mathrm{mg} \mathrm{L}^{-1}\right)$ when the initial bicarbonate concentration was higher than $10 \mathrm{mM}$. During the nitrate reduction, the abundance of nitrate reduction bacteria (NRB) was $22 \%$ in $B 0$, while the abundance of $N R B$ was $3.4 \%$ in B10 and B15. The main functional microbial community in B0 was $N R B$ Brevundimonas, whose abundance was over $19 \%$. During the $U(\mathrm{VI})$, sulfate, and Fe(III) reduction, the abundance of sulfate and Fe reduction bacteria (SRB and FRB) was $44 \%$ in $\mathrm{BO}$, while the abundance of $S R B$ and $F R B$ were $26 \%$ and $27 \%$ in $B 10$ and B15, respectively. The main functional microbial communities capable of reducing $\mathrm{U}(\mathrm{VI})$ in B0 were Cellulomonas, Desulfosporosinus, and Desulfovibrio, whose abundance was as high as $36 \%$. The main microbial community capable of reducing $U(\mathrm{VI})$ in B10 was Desulfitobacterium, and its abundance was higher than 14\%. The main functional microbial communities capable of reducing $U(\mathrm{VI})$ in B15 were Desulfovibrio and Geobacter, and their abundance was over 13\%. The overall experimental results indicate that the higher initial bicarbonate concentration leads to the lower abundance of microbial communities capable of reducing $U(V I)$ in groundwater.
\end{abstract}

\section{Introduction}

Uranium mining and processing in the nuclear industry have resulted in contamination of groundwater which was due to the release of uranium into the groundwater., ${ }^{\mathbf{1 , 2}}$ Uranium commonly appears as soluble U(VI) or sparingly soluble U(Iv) phases and exists in the anaerobic conditions of groundwater. ${ }^{3,4}$ Soluble U(vI) can migrate with the flowing groundwater. Once it accumulates in the human's body, it will be seriously harmful for people's health. ${ }^{5}$

In the alkaline in situ leaching mining operation, bicarbonate is widely used as an agent to extract uranium from the uranium-bearing ores. ${ }^{6} \mathrm{CO}_{3}{ }^{2-}$ or $\mathrm{HCO}_{3}{ }^{-}$in groundwater can help to form $\mathrm{U}$-carbonate complexes, such as $\mathrm{UO}_{2} \mathrm{CO}_{3}$, $\mathrm{UO}_{2}\left(\mathrm{CO}_{3}\right)_{2}{ }^{2-}$, and $\mathrm{UO}_{2}\left(\mathrm{CO}_{3}\right)_{3}{ }^{4-}$, which resulted in the high mobility of U(vI). ${ }^{7}$ Van Engelen et al. demonstrated that high concentration of bicarbonate in solution promoted the formation of negatively charged uranyl-carbonate complexes and it inhibited the toxicity of $\mathrm{U}(\mathrm{vI})$ to bacteria, but high concentration of bicarbonate reduced the abundance of microbial communities. ${ }^{8}$ Bicarbonate which presents in the groundwater with neutral $\mathrm{pH}$ could decrease the absorption of $\mathrm{U}(\mathrm{vI})$ in sediments. ${ }^{9}$

Key Discipline Laboratory for National Defence for Biotechnology in Uranium Mining and Hydrometallurgy, University of South China, 421001 Hengyang, China. E-mail: dingdxzzz@163.com
Previous studies demonstrated that low concentration of bicarbonate was beneficial for $\mathrm{U}(\mathrm{vI})$ bioreduction in sediment, while high concentration of bicarbonate and sulfate could inhibit the reduction. ${ }^{10}$ Philip E. Long et al. found that when low concentration of bicarbonate existed in groundwater, the abundance of Ca-uranyl-carbonate complexes increased, and acetate-bicarbonate treatments could increase the rate of $\mathrm{U}(\mathrm{vI})$ reduction in the bicarbonate-impacted sediment. ${ }^{11}$ Sheng Ling et al. showed that increasing the concentration of sodium bicarbonate in the system would lead to the slower kinetics for $\mathrm{U}(\mathrm{vI})$ reduction and it would have profound effects on the speciation of $\mathrm{U}(\mathrm{vI})$ in the bacterial cell envelope. ${ }^{12}$ Obviously, these studies made it clear that high concentration of bicarbonate and sulfate would inhibit the $\mathrm{U}(\mathrm{vI})$ bioreduction, acetate-bicarbonate treatments would promote the formation of Ca-uranyl-carbonate complexes. What's more, increasing the concentration of bicarbonate would influence the reduction kinetics and the speciation of $\mathrm{U}(\mathrm{vI})$ on the bacterial cell envelope. High concentration of bicarbonate may be able to inhibit $\mathrm{U}(\mathrm{vI})$ reduction by influencing the abundance of microbial communities capable of reducing $\mathrm{U}(\mathrm{vI})$ in groundwater. However, it is still not clear what concentrations of bicarbonate affect the abundance of microbial communities capable of reducing $\mathrm{U}(\mathrm{vI})$ in groundwater. Nitrate can inhibit $\mathrm{U}(\mathrm{vI})$ bioreduction. ${ }^{13}$ Some $S R B$, including Desulfosporosinus and 
Desulfovibrio, have the ability of reducing $\mathrm{U}(\mathrm{vI}),{ }^{\mathbf{1 4 , 1 5}}$ and some $F R B$, such as Geobacter, can also reduce $\mathrm{U}(\mathrm{vI}) .{ }^{16} \mathrm{U}(\mathrm{vI})$ bioreduction is often after nitrate reduction, and it usually accompanies with sulfate and iron reduction. ${ }^{17}$ Therefore, in studying what concentrations of bicarbonate affect the abundance of microbial communities capable of reducing $\mathrm{U}(\mathrm{vI})$, the impact of $N R B, S R B$ and $F R B$ should also be taken into consideration.

Our previous study demonstrated that high concentration of bicarbonate can inhibit uranium bioreduction, but we did not know what concentrations of bicarbonate in groundwater would affect the bioreduction of uranium and influence the abundance of microbial communities capable of reducing $\mathrm{U}(\mathrm{vI}) .{ }^{18}$ In this paper, each microcosm was prepared with $50 \mathrm{~g}$ sediment and $1000 \mathrm{~mL}$ uranium contaminated groundwater. The sediment was taken from a monitoring well near a uranium tailings repository situated in South China, and the groundwater was also taken from the monitoring well. 7 groups of experiments, which were incubated with lactate and amended with $0,5,10,15,20,25$, and $30 \mathrm{mM}$ initial concentrations of bicarbonate, respectively, were designed. Indigenous microbial communities were stimulated by sodium lactate in the anaerobic microcosms. Functional genes were quantized by qPCR. The abundance of microbial communities was analyzed using Miseq sequencing method.

\section{Materials and methods}

\section{Sample site and sample collection}

Samples were taken from a monitoring well near a uranium mill tailings repository situated in South China. The repository has a subtropical continental climate with an annual average temperature of $17.9{ }^{\circ} \mathrm{C}$, an annual average rainfall of 1452.0 $\mathrm{mm}$, an annual average evaporation capacity of $1324.5 \mathrm{~mm}$, and the altitude from $210.5 \mathrm{~m}$ to $307.0 \mathrm{~m}$ above sea level. It covers an area of approximately $1.70 \mathrm{~km}^{2}$, and contains approximately 188 million $t$ of uranium mill tailings produced by a nearby uranium mill where the uranium ore was processed by the acid leaching from 1960s to 1990s. ${ }^{19}$ Large amounts of waste residue and waste water, which contain nitrate, sulfate, (bi)carbonate, $\mathrm{Ca}^{2+}, \mathrm{Mg}^{2+}, \mathrm{U}$ and other heavy metal ions, and uranium tailings, were discharged into the tailings repository. ${ }^{2}$ These discharged wastes have heavily polluted the surface environment and underground water.

Uranium contaminated groundwater was taken from the monitoring well described above, whose water level was at the depth of $10 \mathrm{~m}$ below the surface. The dissolved oxygen (DO) concentration of the contaminated groundwater was below $0.3 \mathrm{mg} \mathrm{\textrm {L } ^ { - 1 }}$. The sediment samples were collected from the monitoring well, either. All the samples were immediately taken to the laboratory with ice bags under anaerobic conditions, and they were preserved in an anaerobic glove box at the temperature which was lower than $4{ }^{\circ} \mathrm{C}$ until use. ${ }^{20}$ Geochemical compositions of the sediment and groundwater samples were detected before incubation, and the results were shown in Table 1.

\section{Microcosm experiment}

Experimental groups were described above. Each group of the experiment was conducted in triplicate. ${ }^{12}$ For each of 21 sterilized microcosms, $50 \mathrm{~g}$ sediment and $1000 \mathrm{~mL}$ contaminated groundwater were both added into each of them, respectively, ${ }^{21}$ and they were divided into 7 groups as previously described, with each group having three microcosms. 0, 0.42, 0.84, 1.26, $1.68,2.10$ and $2.52 \mathrm{~g}$ of sodium bicarbonate (AR) were dissolved into each group of microcosms, and each group was named as B0, B10, B15, B20, B25, B30, respectively. To make the microcosms reach balance, they were kept motionless for $24 \mathrm{~h}$. The $\mathrm{pH}$ of solutions in all the microcosms was then adjusted to 7.0 with diluted $\mathrm{HCl}$ or $\mathrm{NaOH} .^{12,22}$ After that, $2 \mathrm{~mL}$ sterile sodium lactate was added into each microcosm, and all microcosms were bubbled with the mixed gas of $95 \% \mathrm{~N}_{2}$ and $5 \% \mathrm{H}_{2}$ for half an hour to remove DO in them. Finally, all microcosms were incubated at $20{ }^{\circ} \mathrm{C}$ in dark in the anaerobic glove box. ${ }^{2}$

The interval for taking solution samples was set at 3 days. All the solution samples were collected through the indwelling sampling pump of each microcosm, and they were passed through a $2 \mu \mathrm{m}$ diameter filter for geochemical analysis. Sediment samples were collected at day 10, day 25, and day 64 after incubation for microbiological analysis.

\section{Analytical techniques}

The total U concentration was determined by ICP-MS (Agilent Technologies 7700 Series. USA), and its measurement error was

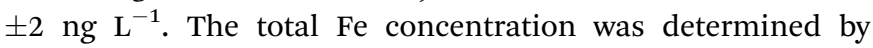
atomic absorption spectrophotometer (PerkinElmer, PinAAcle900F, USA), and its measurement error was $\pm 0.03 \mathrm{mg} \mathrm{L}^{-1}$. The $\mathrm{NO}_{3}{ }^{-}, \mathrm{SO}_{4}{ }^{2-}$, and $\mathrm{CO}_{3}{ }^{2-}$ concentrations were determined by ion chromatography (ICS-900. USA), and their measurement errors were $\pm 0.05 \mathrm{mg} \mathrm{L}{ }^{-1}, \pm 0.1 \mathrm{mg} \mathrm{L}^{-1}$ and $\pm 0.1 \mathrm{mg} \mathrm{L}^{-1}$, respectively. The COD concentration was determined by COD rapid determination instrument (AWM. France), and its measurement error was $\pm 0.1 \mathrm{mg} \mathrm{L}^{-1}$. The metal cation

Table 1 Geochemical characteristics of sediment and groundwater samples used for microcosm experiment

\begin{tabular}{llr}
\hline $\begin{array}{l}\text { Physical and chemical } \\
\text { characteristics }\end{array}$ & $\begin{array}{l}\text { Sediment } \\
\left(\mathrm{g} \mathrm{kg}^{-1}\right)\end{array}$ & $\begin{array}{l}\text { Groundwater } \\
\left(\mathrm{mg} \mathrm{L}^{-1}\right)\end{array}$ \\
\hline $\mathrm{Total} \mathrm{Fe}$ & 7.6 & 0.1 \\
$\mathrm{Mg}$ & 4.5 & 10.2 \\
$\mathrm{Ca}$ & 1.7 & 106.5 \\
$\mathrm{Mn}$ & 0.5 & 5.3 \\
$\mathrm{~K}$ & 2.2 & 26.2 \\
$\mathrm{Na}$ & 0.6 & 47.1 \\
$\mathrm{Zn}$ & 1.0 & 0.3 \\
$\mathrm{Cr}$ & 0.02 & 0.5 \\
$\mathrm{U}$ & 0.1 & 6.5 \\
$\mathrm{SO}_{4}{ }^{2-}$ & - & 2790.5 \\
$\mathrm{HCO}{ }_{3}^{-}$ & - & 0.6 \\
$\mathrm{DO}$ & - & 0.3 \\
$\mathrm{COD}$ & - & 11.0 \\
$\mathrm{pH}$ & 6.0 & 6.5
\end{tabular}


concentrations were also determined by atomic absorption spectrophotometer. ${ }^{18}$ The DO concentration was determined by dissolved oxygen meters (INESA JPSJ-605, China). pH was determined by pH-meter (INESA JPSJ-3F, China).

\section{qPCR analyses}

The TM1389, $d s r B$ and $g l t A$, qPCR analyses were performed using SYBR green-based detection chemistry, and their primer pairs were BACT1369/PROK1492R, DSRq1F/DSRq1R and CS375F/ CS598R, respectively. ${ }^{23,24} 25 \mu \mathrm{L}$ qPCR mixtures contained 12.5 $\mu \mathrm{L}$ of SybrGreen qPCR Master Mix, $0.5 \mu \mathrm{L}$ of $10 \mu \mathrm{M}$ concentrations of primer F, $0.5 \mu \mathrm{L}$ of $10 \mu \mathrm{M}$ concentrations of primer R, $9.5 \mu \mathrm{L}$ of $\mathrm{ddH}_{2} \mathrm{O}$, and $2 \mu \mathrm{L}$ cDNA templates. All qPCR experiments were conducted in triplicate. PCR amplification was performed with ABI7500 real-time PCR system. ${ }^{25}$ The thermal cycling for activation included the initial heating at $95{ }^{\circ} \mathrm{C}$ for $10 \mathrm{~min}$, and the 40 cycles with each one including melting at $95{ }^{\circ} \mathrm{C}$ for $15 \mathrm{~s}$ and annealing or extending at $60^{\circ} \mathrm{C}$ for $1 \mathrm{~min}$. Standard curves were drawn using a 10-fold dilution series of quantified plasmid $T M 1389, d s r B$, and gltA gene, respectively.

\section{5 rRNA gene amplicon pyrosequencing}

The triplicate of 16S rRNA genes was amplified from each DNA extract. Two primers (338F [ACTCCTACGGGAGGCAGCA] and 806R [GGACTACHVGGGTWTCTAAT]) were designed for PCR amplification. ${ }^{26}$ Cycling was performed using a TransGenAP22102 (TransStart Fastpfu DNA polymerase, $20 \mu \mathrm{L}$ ). PCRs were performed in a final volume of $20 \mu \mathrm{L}$ mixture, which was obtained by mixing $4 \mu \mathrm{L}$ of $5 \times$ FastPfu Buffer, $2 \mu \mathrm{L}$ of $2.5 \mathrm{mM}$ dNTPs, $0.8 \mu \mathrm{L}$ of forward Primer $(5 \mu \mathrm{M}), 0.8 \mu \mathrm{L}$ of reverse Primer $(5 \mu \mathrm{M}), 0.4 \mu \mathrm{L}$ of FastPfu Polymerase, and $2 \mu \mathrm{L}$ of template DNA together, and diluting the mixture with sterile $\mathrm{ddH}_{2} \mathrm{O}$ to $20 \mu \mathrm{L}$. The amplicon process consists of three steps: (a) the initial denaturation at $95^{\circ} \mathrm{C}$ for $3 \mathrm{~min}$; (b) 27 cycles with each one including heating at $95^{\circ} \mathrm{C}$ for $30 \mathrm{~s}$, at $55{ }^{\circ} \mathrm{C}$ for $30 \mathrm{~s}$, and at $72{ }^{\circ} \mathrm{C}$ for $45 \mathrm{~s}$; and (c) a final extension at $72{ }^{\circ} \mathrm{C}$ for $10 \mathrm{~min}$, and at $10^{\circ} \mathrm{C} .{ }^{27}$ Amplifications were run by PCR instrument (ABI GeneAmp $\left.{ }^{\circledR} 9700\right)$.

Sequences were clustered into OTUs (Operational Taxonomic Units) using Usearch software (version $7.1 \mathrm{http} / / /$ drive5.com/uparse/). In order to obtain the taxonomic information of each OTU cluster, $97 \%$ of similar levels of the OTU were subjected to taxonomic-based analysis using the pipeline initial process of the RDP pyrosequencing pipeline (release 11.3 http://rdp.cme.msu.edu/). ${ }^{28}$ The community composition of each sample was classified as phylum and genus levels by statistical analysis. Based on the statistical analysis results, diversity and abundance of microbial communities were determined for each sample. Furthermore, the heat-map was drawn to show the consequences.

\section{Results and discussion}

\section{Geochemical characteristics of sediment and groundwater samples}

To illustrate the geochemical composition of microcosms, the previous sediment and groundwater samples were detected. The measured data were shown in Table 1. Iron was very abundant in sediments, while it was not detected in groundwater. Therefore, microbial communities would reduce ferric ions in sediment to ferrous ones, and ferrous and ferric cations would migrate to groundwater, accompanied by uranium reduction..$^{29}$ Sediment and groundwater were enriched with calcium, and this resulted in the Ca-uranyl-carbonate complexes with lactate consumption. Thereby, those complexes increased the uranium mobility in groundwater (Table 2). ${ }^{30}$ As buffer, the low concentration of bicarbonate in groundwater could decrease the toxicity of heavy metals to microbial communities. ${ }^{31}$ The carbonate of previous groundwater was in very low concentration. However, after 64 days of incubation, the concentration of carbonate was raised to a high level due to the consumption of lactate. The higher concentration of bicarbonate previously added, the higher the carbonate concentration would be generated (Table 2). The variation of nitrate, uranium, sulfate, $\mathrm{pH}$, and COD will be discussed in the text below.

\section{Variation of nitrate, uranium, sulfate, iron, $\mathrm{pH}$ and COD in solution}

Fig. 1 shows that nitrate concentrations began to decrease after the electron donor was added. In the first 10 days, nitrate concentrations of all groups decreased fast, and the nitrate reduction speed decreased fastest in the group without bicarbonate (B0). This phenomenon indicates that low concentration of bicarbonate is in favor of nitrate reduction. ${ }^{32}$ Nitrate concentrations declined to the detection limit at day 22 in all groups, and they kept unchanged after that.

Uranium concentrations of all experimental groups declined from $6.5 \mathrm{mg} \mathrm{L}^{-1}$ to $4.2-5.4 \mathrm{mg} \mathrm{L}^{-1}$ after all the microcosms were kept motionless for $24 \mathrm{~h}$. The uranium concentration increased with the increase of the initial bicarbonate concentration, but it does not increase proportionally with the bicarbonate concentration. The variation of uranium concentrations in the microcosms is shown in Fig. 1B. It can be observed that $\mathrm{U}(\mathrm{vI})$ was reduced slowly in the first 12 days due to nitrate inhibition, ${ }^{33}$ and since then the concentration of $\mathrm{U}(\mathrm{vr})$ decreased fast. For these groups, the uranium concentration decreased faster in the control group (B0) than in the other groups. The final concentrations of $\mathrm{U}(\mathrm{vI})$ decreased bellow the maximum contaminant limit for uranium wastewater discharge $\left(0.05 \mathrm{mg} \mathrm{L}^{-1}\right)$ by Chinese Environmental Protection Ministry (GB 23727-2009) in B0, B5, B10, and they remained stable. However, uranium concentrations

Table 2 Carbonate concentrations before and after incubation

\begin{tabular}{lc}
\hline Group & Carbonate concentration $\left(\mathrm{mg} \mathrm{L}^{-1}\right)$ \\
\hline Previous groundwater & 14.7 \\
B0 & 1152.2 \\
B5 & 1564.6 \\
B10 & 1865.4 \\
B15 & 2131.7 \\
B20 & 2334.2 \\
B25 & 2443.4 \\
B30 & 2532.5
\end{tabular}



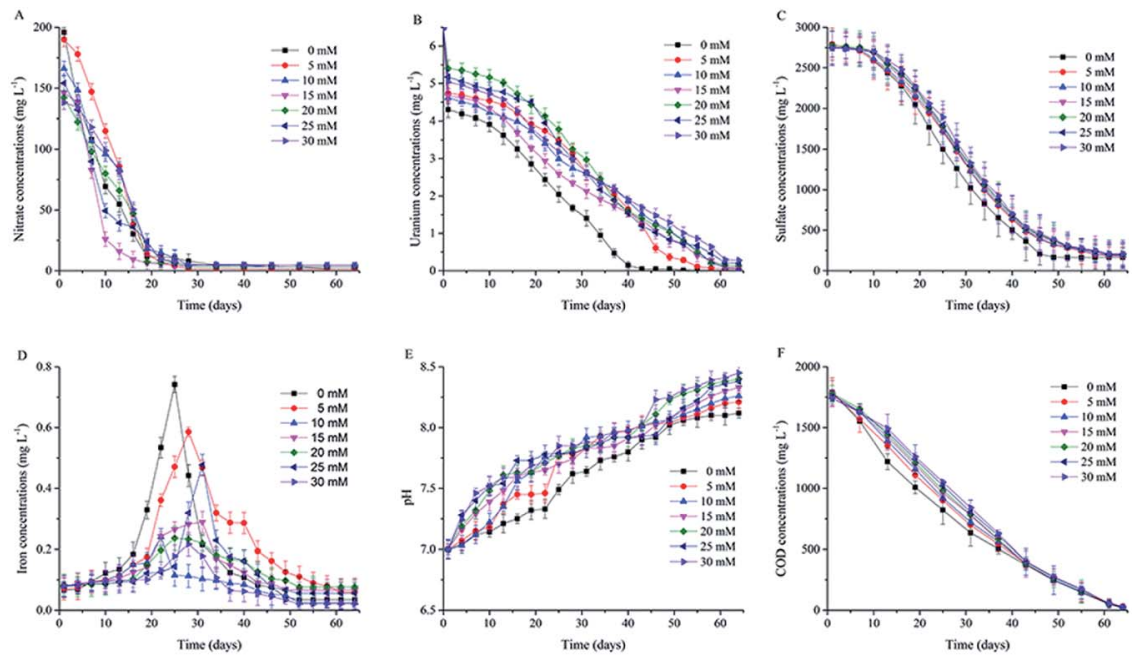

Fig. 1 Variation of nitrate, uranium, sulfate, iron, $\mathrm{pH}$ and $\mathrm{COD}$ in solution during incubation.

remained at 0.1 to $0.28 \mathrm{mg} \mathrm{L}^{-1}$ in other groups depending on the bicarbonate concentration. This phenomenon indicates that $\mathrm{U}(\mathrm{vI})$ concentrations decreased more quickly in the microcosms amended with low concentrations of bicarbonate than in those amended with high concentrations of bicarbonate; what's more, the U(Iv) was more stable in the microcosms amended with low concentrations of bicarbonate. These results obviously illustrated that bicarbonate had the inhibitory effect on U(vI) bioreduction. ${ }^{12,18}$ The reason why the final concentration of $\mathrm{U}(\mathrm{vI})$ was lower in B0 than in other groups was that microbial communities consumed the electron donors and the metabolic $\mathrm{CO}_{3}{ }^{2-}$ was produced by them. The metabolic $\mathrm{CO}_{3}{ }^{2-}$ desorbed the $\mathrm{U}(\mathrm{vI})$ that was previously adsorbed by sediments, which was also reduced by microbial communities. ${ }^{\mathbf{1 1}}$ However, bicarbonate concentrations were too high for microbial communities capable of reducing $\mathrm{U}(\mathrm{vI})$ in other groups. Their reduction ability was inhibited by high bicarbonate concentrations, and they could not decrease the desorbed U(vi) concentrations to the lower level.

Fig. 1C shows that sulfate concentrations in the microcosms decreased slowly in the first 12 days, and then, they decreased faster. The concentration of sulfate in B0 stopped declining and kept stable at day 49. However, the sulfate concentrations in other groups continued declining until day 58. Fig. 1B and C show that $\mathrm{U}(\mathrm{vI})$ reduction accompanied with sulfate reduction. The reason for this was that some kinds of $S R B$ could reduce $\mathrm{U}(\mathrm{vI})$ while they were reducing sulfate. ${ }^{34}$ At the same time, it is clear that the activities of the indigenous microbial communities were inhibited significantly by the high concentration of bicarbonate. ${ }^{35}$

Total iron concentrations were very low before incubation in all groups. After incubation, they increased to peak values ranging from 0.21 to $0.73 \mathrm{mg} \mathrm{L}^{-1}$ between day 22 and day 31 . Then, they began to decline (Fig. 1D). The reason for the increase was that iron was reduced by FRB in sediment; and the reduction resulted in the increase of total iron concentration. ${ }^{36}$ The subsequent decrease was due to the precipitation of biogenic Fe(II). ${ }^{37}$ Total iron concentrations increased faster in the low bicarbonate concentration groups ( $0 \mathrm{mM}$ and $5 \mathrm{mM}$ ) than in other groups, and their peak values were higher. This can be attributed to the growth promotion of the low bicarbonate concentration on the indigenous microbial communities. ${ }^{12}$

It can be seen that the $\mathrm{pH}$ of all the microcosms increased to 8.12-8.45 after 64 days of incubation in Fig. 1E. The reason for this was that the microbial communities continuously consumed electron donors and produced carbonate in the solutions (Table 2). ${ }^{11}$ Significantly, the higher the previous bicarbonate concentrations, the higher the $\mathrm{pH}$ would be.

Fig. $1 \mathrm{~F}$ shows the variation of COD concentrations in the microcosms. COD concentrations decreased quickly as soon as incubation began. The COD was consumed faster in B0 than in other groups since the microbial communities were more active in B0 before the sulfate reduction. After the sulfate was completely reduced, COD was only used to maintain the activities of the microbial communities. ${ }^{38}$

Based on the above results, we chose the control group (B0), the group whose $\mathrm{U}(\mathrm{vI})$ concentration could decrease to $0.05 \mathrm{mg} \mathrm{L}^{-1}$ (B10), and the group whose $\mathrm{U}(\mathrm{vI})$ concentration could not decrease to $0.05 \mathrm{mg} \mathrm{L}^{-1}$ (B15) for, qPCR, and PCR amplification analyses.

\section{qPCR results}

$T M 1389, d s r B$, and $g l t A$ are the gene of Eubacteria, $S R B$, and FRB, respectively. The variations of the numbers of TM1389, $d s r B$, and gltA can reflect their growth..$^{25,39}$ In order to quantify TM1389, dsrB and gltA, qPCR was used to analyze sediment samples at day $0,10,25,37$, and 64, respectively. Fig. 2 shows that the growth of Eubacteria, $S R B$ and gltA was detected at the five key time points. During uranium, iron and sulfate reducing process, the number of TM1389 increased over time, which indicated that microbial communities were growing during this process. ${ }^{40}$ Afterwards, it began to decrease (Fig. 2A), and the activities of the microbial communities also decreased. The number of $d s r B$ was detected to be the highest at day 25 in B0, and it reached $5 \times 10^{3}$ copies per $\mu \mathrm{L}$. However, the numbers of 

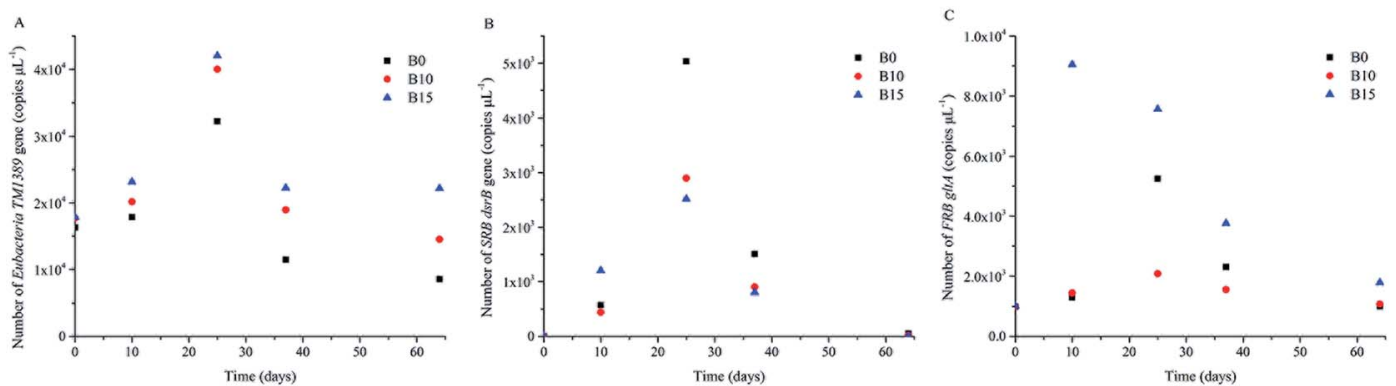

Fig. 2 Number of Eubacteria TM1389, SRB dsrB and FRB gltA mRNA gene copies per $\mu$ L total DNA.

$d s r B$ in B10 and B15 were just half of that in B0, which indicated that the lactate stimulated $S R B$ were more active in B0 than in $\mathrm{B} 10$ and B15. The transcriptional peak of $d s r B$ was agreeable with the result of 16S rRNA gene pyrosequencing, and they showed that the dominant genus of $S R B$, including Desulfitobacterium, Desulfobulbus, Desulfosporosinus, Desulfovibrio, and Desulfurispora, were detected. ${ }^{26,41,42}$ The number of gltA was detected to be very high at day 10 in B15, while it was tested to be very low in B0 and B10. The transcriptional peak of gltA was in agreement with the result of the 16S rRNA gene pyrosequencing, and they showed that Geobacter and Geothrix were detected at day 10 in $\mathrm{B} 15 .{ }^{25,43}$ At day 25, the number of gltA increased to $5.2 \times 10^{3}$ copies per $\mu \mathrm{L}$ in B0, while the number of gltA decreased a little in B15. The main function microbial community was Geobacter in B0 and B15. This phenomenon indicated that the lactate stimulated $F R B$ were more active in B15 than in B0 and B10.

\section{Abundance of the functionalized indigenous microbial communities during bioreduction}

In order to study the abundance of the functionalized indigenous microbial communities in the microcosms amended with lactate, the amplification microarray was used to analyze the preliminary sediment and the sediments of B0, B10 and B15 which were sampled at day 10 and 25 , respectively. Fig. 3 illustrates that the compositions of microbial communities whose abundance is more than $1 \% .{ }^{44}$ Microbial communities, including Bacillus, Brevundimonas, Carnobacterium, Enterococcus, Lactococcus, Lysinibacillus, Solibacillus, Spirochaeta, and Sporosarcina, were detected in the preliminary sediment. Among these microbial communities, only Brevundimonas was reported to have the ability of reducing nitrate, ${ }^{\mathbf{4 5}}$ which indicated that functionalized indigenous microbial communities cannot be stimulated without adding electron donor.

At day 10, microbial communities, including Bradyrhizobium, Enterococcus, Sphingomonas, and Xanthobacter, were simultaneously found in the three groups. Among these microbial communities, Sphingomonas is able to bioprecipitate uranium from alkaline solutions, ${ }^{46}$ and Bradyrhizobium can precipitate metallic cations. ${ }^{47}$ Microbial communities, including Algoriphagus, Anaerolinea, Azospirillum, Brevundimonas, Devosia, Flavobacterium, Luteimonas, Pseudoxanthobacter, Reyranella, Sphingopyxis, and Rhizobium, were also detected in B0. Of which,
Azospirillum, Brevundimonas, and Rhizobium are nitrate reducing bacteria. ${ }^{\mathbf{4 5 , 4 8 , 4 9}}$ Some microbial communities were detected in B10, including Bacillus, Bacteroides, Brevundimonas, Burkholderia, Dialister, Lactococcus, Lysinibacillus, Nevskia, Novosphingobium, Prevotella, Solibacillus, and Sporosarcina. Among aforementioned microbial communities, Brevundimonas is a kind of nitrate reducing bacteria which previously mentioned, so is Novosphingobium.$^{50}$ Bacteroides is a kind of enzyme capable of reducing sulfate, ${ }^{51}$ and Burkholderia can reduce the toxicity of nickel and uranium. ${ }^{52}$ And the microbial communities were detected in B15, including Acidovorax, Bacteroides, Burkholderia, Dechloromonas, Desulfovibrio, Dialister, Faecalibacterium, Geobacter, Geothrix, Lactococcus, Methyloversatilis, Nevskia, Prevotella, and Solibacillus. Thereinto, Acidovorax has the ability to remove uranium from solution, ${ }^{53}$ Bacteroides is a kind of enzyme capable of reducing

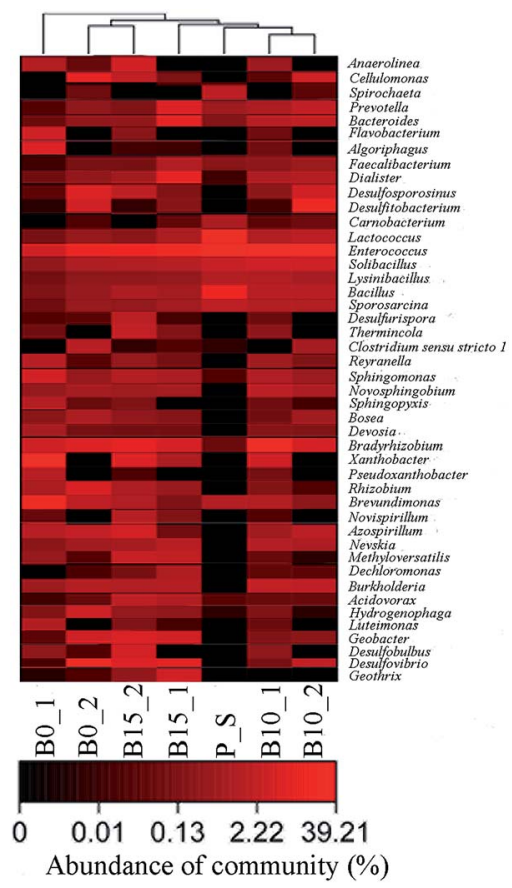

Fig. 3 Abundance of microbial communities in response to lactate and bicarbonate treatments. P_S is the preliminary sediment. B0_1, B10_1, and B15_1 indicate the functionalized indigenous microbial communities in B0, B10 and B15, respectively, at day 10; and B0_2, B10_2, and B15_2 indicate the functionalized indigenous microbial communities in B0, B10 and B15, respectively, at day 25 . 
sulfate which previously mentioned, Burkholderia can reduce nickel and uranium toxicity which is previously stated, Dechloromonas can reduce nitrate and oxidize Fe(II), ${ }^{54}$ Desulfovibrio is a sulfate reducing bacteria which can reduce sulfate and $\mathrm{U}(\mathrm{vI}){ }^{15}$ Geobacter is an Fe(III)- and U(vI)-reducing bacterium, ${ }^{\mathbf{1 6}}$ Geothrix is a kind of iron reducing bacteria, ${ }^{55}$ and Methyloversatilis can reduce nitrate to nitrite. ${ }^{56}$ During this period, nitrate reduction proceeded faster in B0 than in the other two groups (Fig. 1A). The reason for this was that the abundance of the nitrate reducing bacteria was over $20 \%$ in B0, while the abundance of the nitrate reducing bacteria was only $3.4 \%$ in $\mathrm{B} 10$ and $\mathrm{B} 15$. The main functional microbial community was the NRB Brevundimonas in B0, and its abundance was up to $19 \%$. Although $S R B$ and $F R B$ were detected in $\mathrm{B} 15$, the nitrate inhibited the reduction of $\mathrm{U}(\mathrm{vI})$, sulfate, and Fe(III) (Fig. 1B-D). ${ }^{17}$

At day 25, many microbial communities, including Azospirillum, Bradyrhizobium, Burkholderia, Cellulomonas, Desulfosporosinus, Desulfovibrio, Enterococcus, and Solibacillus, were simultaneously detected in the three groups. The functional microbial communities including Azospirillum, Bradyrhizobium, and Desulfovibrio have been described above. Cellulomonas is a kind of dissimilatory reduction bacteria capable of reducing $\mathrm{Cr}(\mathrm{VI}), \mathrm{Fe}(\mathrm{III})$, and $\mathrm{U}(\mathrm{VI}),{ }^{57}$ and Desulfosporosinus is a kind of sulfate reduction bacteria capable of reducing sulfate and $\mathrm{U}(\mathrm{vI}) \cdot{ }^{14}$ Some other microbial communities were detected in B0, including Bosea, Brevundimonas, Clostridium_sensu_stricto_1, Desulfitobacterium, Geobacter, Hydrogenophaga, and Rhizobium. The functions of Brevundimonas, Geobacter, and Rhizobium, have been described above. Clostridium_sensu_stricto_1 can reduce nitrate and nitrite, ${ }^{58}$ and Desulfitobacterium can reduce sulfate and U(vi). ${ }^{59}$ The abundance of $S R B$ and $F R B$ was $44 \%$ in B0. The main functional microbial communities capable of reducing $\mathrm{U}(\mathrm{vI})$ were Cellulomonas, Desulfosporosinus, and Desulfovibrio, whose abundance was up to $36 \%$. Many other microbial communities, including Bacillus, Bacteroides, Desulfitobacterium, Dialister, Lactococcus, Nevskia, Novosphingobium, Prevotella, and Sporosarcina, were found in B10. All the functional microbial communities including Bacteroides, Novosphingobium, and Desulfitobacterium, have been described before. The abundance of $S R B$ and $F R B$ was $27 \%$ in B10. The main functional microbial community capable of reducing $\mathrm{U}(\mathrm{vI})$ was Desulfitobacterium, and its abundance was up to $14 \%$. The microbial communities including Acidovorax, Anaerolinea, Bacillus, Brevundimonas, Desulfobulbus, Desulfurispora, Geobacter, Methyloversatilis, Novispirillum, Rhizobium, Sphingomonas, Thermincola, and Xanthobacter were detected in B15. Among these microbial communities, the functional microbial communities, including Acidovorax, Brevundimonas, Geobacter, Methyloversatilis, Sphingomonas, and Rhizobium, have been described previously. Desulfobulbus and Desulfurispora are sulfate reduction bacteria. ${ }^{\mathbf{4 2 , 6 0}}$ The abundance of $S R B$ and FRB was $44 \%$ in B15. The main functional microbial communities capable of reducing U(v) were Desulfovibrio and Geobacter, and their abundance was up to $13 \%$. During this period, $\mathrm{U}(\mathrm{vI})$ reduction proceeded faster in B0 than in B10 and B15 (Fig. 1B). The reason for this was that the abundance of $S R B$ and FRB capable of reducing $\mathrm{U}(\mathrm{vI})$ was higher in B0 than in B10 and B15.
Sulfate reduction speed was also higher in B0 than in B10 and B15 (Fig. 1C), which was due to the fact that the abundance of $S R B$ was higher in B0 than in the other two groups. Since the activity of $F R B$ was the highest in B0, the concentration of the total iron in the solution was also the highest in it. These results were agreeable with the whole reduction process (Fig. 1).

\section{Conclusions}

7 groups of experiments with 7 initial concentrations of bicarbonate $(0,5,10,15,20,25$, and $30 \mathrm{mM})$ were conducted, and the results showed that the $\mathrm{U}(\mathrm{VI})$ concentration could not be decreased below the Chinese uranium wastewater discharge standard $\left(0.05 \mathrm{mg} \mathrm{L}^{-1}\right)$ when the initial bicarbonate concentration was higher than $10 \mathrm{mM}$. Miseq sequencing results showed that while the nitrate was being reduced, the main functional microbial community was a kind of NRB Brevundimonas in B0, and its abundance was 19\%. Moreover, while U(vI), sulfate and $\mathrm{Fe}(\mathrm{III})$ were being reduced, it was found that the main functional microbial communities capable of reducing U(vi) were Cellulomonas, Desulfosporosinus, and Desulfovibrio in B0 and their abundance was higher than 36\%, that the main functional microbial communities capable of reducing U(vI) was Desulfitobacterium in B10 and its abundance was 14\%, and that the main function microbial communities capable of reducing $\mathrm{U}(\mathrm{vI})$ were Desulfovibrio and Geobacter in B15 and their abundance was over $13 \%$. The experimental results indicate that the higher initial bicarbonate concentration leads to the lower abundance of microbial communities capable of reducing $\mathrm{U}(\mathrm{vI})$ in groundwater.

\section{Conflicts of interest}

There are no conflicts to declare.

\section{Acknowledgements}

This work was supported by the National Natural Science Foundation of China (No. U1401231 and 51274124) and the Defense Industrial Technology Development Program (No. B3720132001).

\section{References}

1 C. Hwang, W. Wu, T. J. Gentry, J. Carley, G. A. Corbin, S. L. Carroll, D. B. Watson, P. M. Jardine, J. Zhou, C. S. Criddle and M. W. Fields, ISME J., 2009, 3, 47-64.

2 D. Ding, F. Xu, N. Hu, S. Li, X. Tan and G. Li, J. Radioanal. Nucl. Chem., 2015, 303, 925-933.

3 D. M. Singer, J. M. Zachara and G. E. Brown Jr, Environ. Sci. Technol., 2009, 43, 630-636.

4 M. J. Marshall, A. S. Beliaev, A. C. Dohnalkova, D. W. Kennedy, L. Shi, Z. Wang, M. I. Boyanov, B. Lai, K. M. Kemner, J. S. McLean, S. B. Reed, D. E. Culley, V. L. Bailey, C. J. Simonson, D. A. Saffarini, M. F. Romine, J. M. Zachara and J. K. Fredrickson, PLoS Biol., 2006, 4, e268. 
5 L. M. Camacho, S. Deng and R. R. Parra, J. Hazard. Mater., 2010, 175, 393-398.

6 E. A. Santos and A. C. Q. Ladeira, Environ. Sci. Technol., 2011, 45, 3591-3597.

7 S. Regenspurg, D. Schild, T. Schäfer, F. Huber and M. E. Malmström, Appl. Geochem., 2009, 24, 1617-1625.

8 M. R. VanEngelen, E. K. Field, R. Gerlach, B. D. Lee, W. A. Apel and B. M. Peyton, Environ. Toxicol. Chem., 2010, 29, 763-769.

9 L. Sheng and J. B. Fein, Chem. Geol., 2013, 358, 15-22.

10 W. Luo, W. Wu, T. Yan, C. S. Criddle, P. M. Jardine, J. Zhou and B. Gu, Appl. Microbiol. Biotechnol., 2007, 77, 713-721.

11 P. E. Long, K. H. Williams, J. A. Davis, P. M. Fox, M. J. Wilkins, S. B. Yabusaki, Y. Fang, S. R. Waichler, E. S. F. Berman, M. Gupta, D. P. Chandler, C. Murray, A. D. Peacock, L. Giloteaux, K. M. Handley, D. R. Lovley and J. F. Banfield, Geochim. Cosmochim. Acta, 2015, 150, 106-124.

12 L. Sheng and J. B. Fein, Environ. Sci. Technol., 2014, 48, 37683775.

13 W. Wu, J. Carley, S. J. Green, J. Luo, S. D. Kelly, J. V. Nostrand, K. Lowe, T. Mehlhorn, S. Carroll, B. Boonchayanant, F. E. Löfller, D. Watson, K. M. Kemner, J. Zhou, P. K. Kitanidis, J. E. Kostka, P. M. Jardine and C. S. Criddle, Environ. Sci. Technol., 2010, 44, 5104-5111.

14 E. J. O'Loughlin, S. D. Kelly, R. E. Cook, R. Csencsits and K. M. Kemner, Environ. Sci. Technol., 2003, 37, 721-727.

15 R. K. Sani, B. M. Peyton and A. Dohnalkova, Environ. Toxicol. Chem., 2006, 25, 1231-1238.

16 O. Prakash, T. M. Gihring, D. D. Dalton, K. Chin, S. J. Green, D. M. Akob, G. Wanger and J. E. Kostka, Int. J. Syst. Evol. Microbiol., 2010, 60, 546-553.

17 D. M. Akob, L. Kerkhof, K. Küsel, D. B. Watson, A. V. Palumbo and J. E. Kostka, Appl. Environ. Microbiol., 2011, 77, 8197-8200.

18 D. Li, N. Hu, D. Ding, S. Li, G. Li and Y. Wang, J. Radioanal. Nucl. Chem., 2016, 307, 1011-1019.

19 G. Li, N. Hu, D. Ding, J. Zheng, Y. Liu, Y. Wang and X. Nie, Bull. Environ. Contam. Toxicol., 2011, 86, 646-652.

20 D. S. Alessi, J. S. Lezama-Pacheco, N. Janot, E. I. Suvorova, J. M. Cerrato, D. E. Giammar, J. A. Davis, P. M. Fox, K. H. Williams, P. E. Long, K. M. Handley, R. BernierLatmani and J. R. Bargar, Environ. Sci. Technol., 2014, 48, 12842-12850.

21 Y. Suzuki, S. D. Kelly, K. M. Kemner and J. F. Banfield, Appl. Environ. Microbiol., 2003, 69, 1337-1346.

22 D. S. Alessi, J. S. Lezama-Pacheco, J. E. Stubbs, M. Janousch, J. R. Bargar, P. Persson and R. Bernier-Latmani, Geochim. Cosmochim. Acta, 2014, 131, 115-127.

23 B. K. Amos, Y. Sung, K. E. Fletcher, T. J. Gentry, W. Wu, C. S. Criddle, J. Zhou and F. E. Löffler, Appl. Environ. Microbiol., 2007, 73, 6898-6904.

24 D. E. Holmes, L. Giloteaux, A. K. Chaurasia, K. H. Williams, B. Luef, M. J. Wilkins, K. C. Wrighton, C. A. Thompson, L. R. Comolli and D. R. Lovley, ISME J., 2015, 9, 333-346.

25 M. Miletto, K. H. Williams, A. L. N'Guessan and D. R. Lovley, Appl. Environ. Microbiol., 2011, 77, 6502-6509.
26 M. B. Smith, A. M. Rocha, C. S. Smillie, S. W. Olesen, C. Paradis, L. Wu, J. H. Campbell, J. L. Fortney, T. L. Mehlhorn, K. A. Lowe, J. E. Earles, J. Phillips, S. M. Techtmann, D. C. Joyner, D. A. Elias, K. L. Bailey, R. A. Hurt, S. P. Preheim, M. C. Sanders, J. Yang, M. A. Mueller, S. Brooks, D. B. Watson, P. Zhang, Z. He, E. A. Dubinsky, P. D. Adams, A. P. Arkin, M. W. Fields, J. Zhou, E. J. Alm and T. C. Hazen, mBio, 2015, 6, e00326.

27 E. L. Brodie, T. Z. DeSantis, D. C. Joyner, S. M. Baek, J. T. Larsen, G. L. Andersen, T. C. Hazen, P. M. Richardson, D. J. Herman, T. K. Tokunaga, J. M. Wan and M. K. Firestone, Appl. Environ. Microbiol., 2006, 72, 6288-6298.

28 L. Oberauner, C. Zachow, S. Lackner, C. Högenauer, K. Smolle and G. Berg, Sci. Rep., 2013, 3, 1413.

29 E. R. Gilson, S. Huang and P. R. Jaffé, Biodegradation, 2015, 26, 475-482.

30 L. Sheng, J. Szymanowski and J. B. Fein, Geochim. Cosmochim. Acta, 2011, 75, 3558-3567.

31 R. K. Sani, B. M. Peyton and A. Dohnalkova, Water Res., 2008, 42, 2993-3002.

32 P. Larese-Casanova, S. B. Haderlein and A. Kappler, Geochim. Cosmochim. Acta, 2010, 74, 3721-3734.

33 S. K. Chatterjee, I. Bhattacharjee and G. Chandra, J. Hazard. Mater., 2010, 175, 117-125.

34 E. Cardenas, W. Wu, M. B. Leigh, J. Carley, S. Carroll, T. Gentry, J. Luo, D. Watson, B. Gu, M. Ginder-Vogel, P. K. Kitanidis, P. M. Jardine, J. Zhou, C. S. Criddle, T. L. Marsh and J. M. Tiedje, Appl. Environ. Microbiol., 2010, 76, 6778-6786.

35 J. Luo, F. Weber, O. A. Cirpka, W. Wu, J. L. Nyman, J. Carley, P. M. Jardine, C. S. Criddle and P. K. Kitanidis, J. Contam. Hydrol., 2007, 92, 129-148.

36 M. B. Leigh, W. Wu, E. Cardenas, O. Uhlik, S. Carroll, T. Gentry, T. L. Marsh, J. Zhou, P. Jardine, C. S. Criddle and J. M. Tiedje, Front. Environ. Sci. Eng., 2015, 9, 453-464.

37 H. S. Moon, L. McGuinness, R. K. Kukkadapu, A. D. Peacock, J. Komlos, L. J. Kerkhof, P. E. Long and P. R. Jaffé, Water Res., 2010, 44, 4015-4028.

38 M. D. Tucker, L. L. Barton and B. M. Thomson, J. Ind. Microbiol. Biotechnol., 1998, 20, 13-19.

39 M. Barlett, H. S. Moon, A. A. Peacock, D. B. Hedrick, K. H. Williams, P. E. Long, D. Lovley and P. R. Jaffe, Biodegradation, 2012, 23, 535-546.

40 H. S. Moon, L. McGuinness, R. K. Kukkadapu, A. D. Peacock, J. Komlos, L. J. Kerkhof, P. E. Long and P. R. Jaffé, Water Res., 2010, 44, 4015-4028.

41 T. M. Gihring, G. Zhang, C. C. Brandt, S. C. Brooks, J. H. Campbell, S. Carroll, C. S. Criddle, S. J. Green, P. Jardine, J. E. Kostka, K. Lowe, T. L. Mehlhorn, W. Overholt, D. B. Watson, Z. Yang, W. Wu and C. W. Schadt, Appl. Environ. Microbiol., 2011, 77, 5955-5965. 42 Z. Yi, K. Tan, A. Tan, Z. Yu and S. Wang, Int. Biodeterior. Biodegrad., 2007, 60, 258-266.

43 D. L. Cologgi, A. M. Speers, B. A. Bullard, S. D. Kelly and G. Reguera, Appl. Environ. Microbiol., 2014, 80, 6638-6646. 
44 D. P. Chandler, C. Knickerbocker, L. Bryant, J. Golova, C. Wiles, K. H. Williams, A. D. Peacock and P. E. Long, Appl. Environ. Microbiol., 2013, 79, 799-807.

45 S. Kavitha, R. Selvakumar, M. Sathishkumar, K. Swaminathan, P. Lakshmanaperumalsamy, A. Singh and S. K. Jain, Water Sci. Technol., 2009, 60, 517.

46 K. S. Nilgiriwala, A. Alahari, A. S. Rao and S. K. Apte, Appl. Environ. Microbiol., 2008, 74, 5516-5523.

47 J. Corzo, M. León-Barrios, V. Hernando-Rico and A. M. Gutierrez-Navarro, Appl. Environ. Microbiol., 1994, 60, 4531-4536.

48 H. M. El-Komy, M. A. Hamdia and G. K. Abd El-Baki, Biol. Plant., 2003, 46, 281-287.

49 J. A. G. Silveira, J. C. S. Matos, V. M. Cecatto, R. A. Viegas and J. T. A. Oliveira, Environ. Exp. Bot., 2001, 46, 37-46.

50 D. Zhang, Y. Liu and H. Huang, Antonie van Leeuwenhoek, 2017, 110, 19-25.

$51 \mathrm{H}$. Setoyama, A. Imaoka, H. Ishikawa and Y. Umesaki, Microbes Infect., 2003, 5, 115-122.

52 J. D. Van Nostrand, T. J. Khijniak, B. Neely, M. A. Sattar, A. G. Sowder, G. Mills, P. M. Bertsch and P. J. Morris, Environ. Sci. Technol., 2007, 41, 1877-1882.
53 U. Gerber, I. Zirnstein, E. Krawczyk-Bärsch, H. Lünsdorf, T. Arnold and M. L. Merroun, J. Hazard. Mater., 2016, 317, 127-134.

54 A. Chakraborty and F. Picardal, World J. Microbiol. Biotechnol., 2013, 29, 617-623.

55 K. P. Nevin and D. R. Lovley, Appl. Environ. Microbiol., 2002, 68, 2294-2299.

56 I. Mustakhimov, M. G. Kalyuzhnaya, M. E. Lidstrom and L. Chistoserdova, J. Bacteriol., 2013, 195, 2207-2211.

57 R. Sani, B. Peyton, W. Smith, W. Apel and J. Petersen, Appl. Microbiol. Biotechnol., 2002, 60, 192-199.

58 X. F. Hospital, E. Hierro, S. Stringer and M. Fernández, Int. J. Food Microbiol., 2016, 218, 66-70.

59 K. E. Fletcher, M. I. Boyanov, S. H. Thomas, Q. Wu, K. M. Kemner and F. E. Löffler, Environ. Sci. Technol., 2010, 44, 4705-4709.

60 A. H. Kaksonen, S. Spring, P. Schumann, R. M. Kroppenstedt and J. A. Puhakka, Int. J. Syst. Evol. Microbiol., 2007, 57, 10891094. 